\title{
Schuller Csaba
}

\section{Sport általı ıdentıtáskonstrukcı́ a késő modernitásban}

\section{Bevezető}

A sport az életünk részévé vált. Akár gyakoroljuk, akár csak a híreket nézzük, nem vonhatjuk ki magunkat a hatása alól. A stadionépítések kapcsán, a futballválogatottunk Eb-szereplése ürügyén, vagy azért, mert mi magunk sportolunk - beszivárog az életünkbe. Napról napra nő azon emberek tábora, akik a Margitszigeten róják a köröket egy valamelyik „multinál” töltött fárasztó munkanap után. A közösségi oldalakon az „ételes”, „bulizós”, „szerelmes szelfik” után az egyik legnépszerűbb „az első félmaratonom” hashtag. Széles körben vált újra népszerűvé a napi szintű testedzés. Ha egy jelenség ilyen mértékben elterjedt, tömegeket érintő tevékenységgé válik, akkor nem lehet nem társadalmi aktusként értelmezni, és nem rátekinteni a szociológia szürőjén keresztül.

Dolgozatom elméleti keretét Anthony Giddens és Ulrich Beck későmodernitás-elméletei, valamint a francia individuumszociológia állításai jelölik ki. Megkülönböztetem a sport pozitív elaboratív és negatív patológiás alkalmazását a cselekvő életében; Axel Honneth elismeréselméletével magyarázom az ontológiai biztonság megőrzésére tett kísérleteket. Azt állítom, hogy ezek a stratégiák a társadalomban gyökereznek, de a személyiségben, a lélekben lecsapódó feszültségek hatására manifesztálódnak, és válnak alakítójává a folyamatot elindító környezetnek. A tanulmány középpontjába a futást állítom, mivel egy bizonyos társadalmi csoporton belül a testedzés ezen formája rendkívüli módon elterjedt, és évről évre nagyobb tömeget vonz be. A futás identitáskonstrukcióban betöltött szerepét narratív interjúkon alapuló esettanulmány segítségével mutatom be. A narratívákon keresztül kiemelem és bemutatom azokat a sajátosságokat, amelyek mentén interjúalanyaim az elismerés által megszerezhető ontológiai biztonságot a sport emancipatorikus, illetve patológiás formájában igyekeznek magukévá tenni. Rávilágítok arra a makroszintű dialektikára is, amely az egyedivé válást kíséri az egyéni cselekvő életében. 


\section{A sport mint társadalmi konstrukció}

Norbert Elias (2008) szerint a sportolás által a széles tömegek belsővé tették a formálódó, az erőszakos fellépést monopolizáló, arra egyedüli jogot formáló állam által diktált restriktív szankciókat és szabályokat. És itt nem csak jogi szabályozásról beszélünk. Nyilván ez adta meg az alapot, amelynek számonkérése esetén az esetleges retorziók, elrettentések lehetővé tették, hogy belső normává váljanak addig csak az intézményesült kényszer jeleként definiált beavatkozások. Ugyanakkor a feszültségek nem csökkentek, sőt; az urbanizált életmód növekedésével még nőttek is a mindennapos súrlódások, nézeteltérések. Hogy ez nem torkollott tömeges erőszakba, azt Elias szerint többek között annak köszönhetjük, hogy a sport által a felgyülemlett feszültségek, mindennapos sérelmek becsatornázódhattak olyan szervezett keretek közé szorított megmérettetésekbe, ahol a feszültség kontrollált körülmények között feloldódhatott, még akkor is, ha az egyén csak szurkolóként, nem pedig játékosként vett részt. Elias és az ő civilizatorikus magyarázata mellett természetesen megjelennek egyéb megközelítések is. Az evolúciós pszichológia egy olyan, viszonylag fiatal diszciplína, amely nagy hatékonysággal és magabiztossággal ad választ a társadalom széles rétegeit érintő és azok érdeklődésére számot tartó kérdésekre. Mivel a dolgozatom keretei nem teszik lehetővé az átfogó szakirodalmi áttekintést, ezért csak néhány olyan elméletet, állítást idézek, amelyek rávilágítanak a diskurzus lényegi elemeire. Az evolúciós pszichológia első ránézésre ugyanazt csinálja az egyéni cselekvő magyarázatával, mint az individuumszociológia (Dubet 2012; Takács 2013). Az introspektív megoldáskeresés helyére a makrót, a külsőt, a determinisztikusat állítják. De amíg a francia szociológiai iskolában ez egyfajta egymásra hangolódást, a determináns és a cselekvő táncát feltételezi, megadva a lehetőséget a formálásra, formálódásra, addig az evolúciós pszichológia egy évezredek alatt belénk kódolt biológiai mintázatra hagyatkozik. Evolúciós kényszerekre és szükségszerüségekre, darwini versenyfutásra redukálja a cselekvés minden motivációját. Az objektivitás érdekében el kell mondani, hogy nem vetik el a társadalom, a kultúra befolyásoló erejét, de állításuk szerint a gének rövid pórázon tartják a kultúrát. A sportra és annak szerepére több elmélet is született. Társadalmi dominancia iránti igény, a fertőző kórokozókkal szembeni ellenállás hatékonyabbá tétele, párválasztás, csoporton belüli együttmüködés és a csoporton kívüliekkel való ellenségeskedés, a valahova tartozás iránti igény (Balish et al. 2013).

Az evolúciós pszichológia valóságértelmezésével szemben én a szociológia talaján állva fogalmazom meg állításaimat a sport késő modernitásban betöltött szerepéről. A késő modernitásban alapvetően változott meg az egyén pozíciója. A felvilágosodás ígérete - miszerint Isten halálával, a babonáktól és a transzcendenstől való rettegéssel történő leszámolással majd minden egy csapásra megoldódik, a papok helyére lépő tudósok pedig ugyanolyan magabiztossággal vezetik át a tévelygőt a neonfénnyel bevilágított halál árnyékának völgyén, mint rózsafüzért morzsolgató elődeik - megbukott (Horkheimer és Adorno 1990). A hagyományos struktúrák felbomlásával (Beck 2003) a hosszú időbe (Braudel 2004) beágyazódott cselekvési stratégiák megtartó ereje eltűnt; a Beck által leírt késő modernitásban élő ember számára mindenfajta szolidaritási és viszonyítási csoport, illetve követhető minta eliminálódott. Sem a világot magyarázó nagy narratívák (eposzok, osztály- vagy nemzettudat), sem a jóval személyesebb, ám még így is makrónak ható családi kontinuitás nem jelent kapaszkodót. Az ahistorikus létbe beleragadt egyéni cselekvő számára az egyetlen viszonyítási pont saját létének tengelye, amely olyan mértékben individualizálja a létezést, hogy a megkapasz- 
kodásra való igény nem is találhat magának más tárgyat, mint saját magát. Illetve, ahogy Beck is állítja (1997), a párkapcsolatokba való menekülés is mutat egy ilyen kényszeres jelleget, hiszen a hagyományosan biztonságot nyújtó struktúrák megingásával az egyén legnagyobb félelme a totális elmagányosodás és izoláció.

A folyamatos reflexív újraalkotás (Mead 1973; Giddens 2013) azt az érzetet keltheti, hogy már egyáltalán nem is vagyok. Ezt a zsigeri félelmet és disztópiát igyekeznek minimumra csökkenteni a cselekvők a „kapcsolati élmény” keresésével. Felszínes kapcsolatok, gyenge kötődések, „megduplázott önzések” (Fromm 1984: 109) jönnek létre, illetve az öndefiníciós spirál során nemegyszer előfordul, hogy a cselekvő életének olyan aspektusaival szembesül, melyekre bármennyire is szeretne hatni, nem tud (Beck 2003). Isten halott (Nietzsche 2003), senki és semmi nem ad értelmet vagy célt a létezésnek, a látszólag értelmetlen szenvedésnek. Míg akár a klasszikus modernitásban is lehetőség volt a véges választási lehetőségek közül kiválasztani bizonyos attribútumok mentén a legideálisabbnak tűnőt, addig ez a késő modernitásban kvázi lehetetlenné válik. A választási lehetőségek száma közel végtelen, ugyanakkor a szakértők hierarchiája megszűnt, akik segítenének eligazodni köztük. Soha nem látott szabadság lehetősége párosul az elképzelhetetlen kiszolgáltatottsággal. Ezt a konstans szorongást nevezi Giddens (Sik 2013) ontológiai bizonytalanságnak. Úgy írja le, mint a globális hálózatok során világszintű létélménnyé váló szorongásegyüttest. Ezt érzik Tokiótól Seattle-ig, Fokvárostól Koppenhágáig. Giddens (2013) szerint ez egy veszélyforrás, és a fejlődési potenciált minden eddiginél jobban magában rejtő társadalmi pillanatkép is egyben. A helyzettel való emancipatorikus életstratégia egy egyenlőbb, demokratikusabb állampolgárokból álló közösségiséget vizionál, míg a patológiás válasz premodern megküzdési stratégiákat preferál: fundamentalizmusokat, provincializmust, „újbarbárságot”. Giddens cselekvéselméletében az ontológiai biztonság megteremtésében alapvető fontosságú a rutinizáció, ${ }^{1}$ ami lehet patológiás (kényszeresség), illetve emancipatorikus (elaboratív). Ilyen rutinizációs tevékenységnek tekintem a sportot.

$\mathrm{Az}$ individuumszociológusok - giddensi alapokon továbbgondolva az egyénre nehezedő terheket - megkülönböztetik a becki individualizációt (Beck 1997) az általuk szingularitásnak nevezett folyamattól. A szingularitás mint egyedivé válás nem csak azt jelenti, hogy egyénként, a közösségből kiszakadva értékelem és érzékelem a világot a fogyasztói miliővel szorosabb kapcsolatot kialakítva, mint egy adott társadalmi osztállyal, hanem azt is, hogy a társadalom olyan végletesen individualizálódó rendszer, ahol gyakorlatilag a társadalmi struktúra is egyedivé válik. Személyekre bomlik, önálló arcot és nevet vesz fel (Martuccelli 2012).Ugyanakkor ez az egyénbe ágyazott konstans dialektika még nem teszi semmissé az érzéseket. Nem írja felül azokat a mechanizmusokat, amelyek alapján egy cselekvő meghatározza a minőségi létezés standardjait. Azokat a viszonyítási pontokat, melyek talán csak rá vonatkoznak, de mégis az interakciók olvasztótégelyében születnek, válnak megfoghatóvá. Ezen a ponton, dolgozatom témájából kifolyólag, segítségül kell hívjam Honneth elismeréselméletét (1997), ugyanis itt egy olyan társadalmi-pszichológiai relációval van dolgunk, amit leginkább az elismerés-megvetés dichotómiájára épülő nagyelmélettel vizsgálhatunk meg közelebbről. Honneth úgy tekint a szubjektumra, mint társadalmi interakciók terméke, és mivel az egyén létérzékelése - ha úgy tetszik, személyisége - az őt

1 Giddens tudatfelosztásában (diszkurzív, gyakorlati, tudattalan) a rutinizáció a tudattalan eszköze, mely a stabil énkép fenntartásában segíti a cselekvőt (Berger 2013). 
körülvevő, őt érintő társadalmi folyamatok produktuma, teljesen valid megközelítés azon kohó ajtaját felnyitni, ahol a személyiség születik. Ugyanis a késő modernitás cselekvőjének minden eddiginél nagyobb szüksége van az elismerésre, hogy olyan autonóm személlyé váljon, aki képes a fokozódó nyomás ellenére - önmaga állandó újradefiniálása - vagy éppen amiatt meghozni a döntéseket. Olyan „vad észleléseket” (Sik 2012: 208) létrehívni, amelyek mentesek mások direkt instrukcióitól, behatásaitól. Ez nem az interakció hiányát jelenti, hiszen Honneth elméletében, amely szorosan épül Mead szimbolikus interakcionizmusára, ez nem is lenne lehetséges. Az elmélet a fentebb már leírt hagyományos viszonyok, nagy- és kiscsoportok útmutatása nélküli megoldási stratégiák létrehozását implikálja a cselekvő felé. Olyan egyéni világértelmezésre hív, amely segít eligazodni és kompetens, tevékeny lényként érzékelni saját magát mint társadalmi cselekvőt. Ez pedig szerinte az elismerésből fakad. Az egyént körülvevő szükebb-tágabb közösség általi elismerésből, lett légyen az bármennyire is átmeneti mind a projektszerű szerveződést (Boltanski 1999), mind pedig az értékkonszenzust tekintve.

Nyilván nincs tökéletes élet. Mármint olyan élet, amely pszichológiai értelemben olyan személyiséget alkot, olyan személyiségjegyekkel ajándékozza meg a cselekvőt, ami akár csak megközelítené valamiféle nemlétező szuperszemélyiség ideáltípusát. Bettelheim (2014) jó szülőre vonatkozó állítása, azt gondolom, használható analógiaként, mert ahogy csak elég jó szülő lehet valaki, úgy tökéletes személyiségü emberré sem válhat senki. A fejlődésünk során érnek olyan behatások, élmények, amelyek meghatározzák a későbbi létélményeinket, cselekedeteinket. Egy általánosnak mondható társadalmi normarendszer pozitív-negatív tengelyén erre vagy arra tolják el az adaptivitásunkat. Azonban ez nem determináns, nem kényszeríti az egyént arra, hogy örökké cipelje a „terheit”, hogy ne tudja felülírni az imperatívuszt, miszerint a történeteink írnak minket. Képes új történetet írni magának, új lapot kezdeni (Rangell 2015; Rogers 2003; Ricoeur 2001; Winnicott 2004). Erre mondja azt Honneth, hogy ez az újraírás lehet társadalmi aktus is. Ugyanakkor, mint mindennek, ennek is megvan a másik oldala. Nem csak az újraírásra, hanem a lapok kitépésére is van lehetőség. Amennyiben nincs meg az elismerés a szeretetben, a jogban, a megbecsülésben, akkor a pszichés és társadalmi halál ugyanúgy elpusztítja az egyént, mint ha fizikálisan bántalmaznák, mint ha valóban meghalna. Ezért minden cselekvő küzd az elismerésért, vagy ha nem is képes arra, hogy küzdjön, de megvan benne az igény, hogy elismerjék. Azt gondolom, hogy a témám szempontjából vizsgált sportolói attitüdnél kiemelten megfigyelhető ez a tendencia a lélek és a társadalmi pozíció egyéni - és mégis mélységesen társadalmi - genezisében, hiszen mind a Giddens által leírt ontológiai biztonságra való törekvés, mind a honnethi elismerésért folytatott küzdelem megjelenhet sportba ágyazott tevékenységként. A késő modernitás aktív cselekvője, aki sok esetben kontrollálhatatlan események függvényeként tekint saját életére, visszahúzódik az egyetlen olyan terrénumra, ahol kompetens módon manipulálhat - ez pedig a saját teste.

\section{Módszertani megfontolások}

A késő modernitásban, amikor az egyéni életutak ennyire szerteágazóak lehetnek, az individuumszociológusok szerint a narratívák, az egyéni történetek sokkal fontosabbak, és ezeket kvalitatív módon hatékonyabban lehet felismerni (Takács 2013). Az individuumszociológia 
mellett a szociálpszichológiának egy meghatározó ága szintén erre az eredményre jutott: a valóságot, az egyén pszichéjét valójában a történetek konstruálják. Paul Ricoeur (2001) szerint a narratív azonosság, ami talán megfeleltethető Giddens - az ontológiai biztonság érdekében tett - rutinizációs tevékenységének, ${ }^{2}$ egy olyan állapot, amelyet az egyén az elbeszélőfunkció használata révén ér el. Ebben a megközelítésben az identitás nem egy konstans létező, mely egy teleologikus fejlődés végpontján található, hanem jóval flexibilisebb, formálhatóbb, bármikor felülírható és újraalkotható a történeteink által. Ezek a változások megismerhetők, a mozgatórugók feltárhatók a történet megértése révén, amely történetnek megvannak a maga szabályai. Először is minden történet elindul valahonnan és el akar jutni valahová. Mindemellett a történeteknek megvannak a maguk jól bejáratott szereplői és fordulatai. Az én tulajdonképpen a történeteken, a narrátorokon keresztül konstruálódik, jön létre, de amikor egy narratíva a társas térben legitimmé válik, a befogadón legalább annyi múlik, mint a „mesélőn”. Ha a másik megkérdőjelezi a történet valóságtartalmát, akkor az egész narratíva összeomolhat, de nem csak a mesélőé, hanem - visszatámadás esetén - az ellenállóé is (Gergen J. K. és Gergen M. M. 2001). Az is nagyon fontos, hogy milyen kontextusban, kulturális környezetben próbálják értelmezni a történetet. Csakis az adott kódrendszerrel rendelkezők tudják a narratívát magukévá tenni, és ezáltal hozzájárulni a másik személyiségének megkonstruálásához. Nincsenek magukban álló történetek és magukban álló cselekvők. Az individuumon keresztül gyakorlatilag az adott kultúra mesél magáról és teremti meg magát a narratívát magáévá tevő emberrel együtt (Ricoeur 2001).

Kutatásom során négy narratív interjút vettem fel, de mivel jelen dolgozat keretei nem tették volna lehetővé mind a négy komplex bemutatását, ezért csak egyet ismertetek. Maga az interjúhelyzet kötetlen volt. Igyekeztem a helyzetet oldani, hogy ne szorongjanak az interjúalanyok, de ne is befolyásoljam öket túlzottan. A kérdések során tartottam magam ahhoz, hogy szigorúan a mesélő szóhasználatával, már elhangzott kifejezések ismétlésével kérdeztem vissza egy-egy részletre. Folyamatosan jegyzeteket készítettem, és diktafonra vettem az elmondottakat. Amennyire lehetett, igyekeztem figyelni a nonverbális kommunikációra. Volt, hogy könnyebben ment, volt, hogy nehezebben, ezért ezekre csak elvétve, nagyon ritkán hivatkozok az elemzésnél. A szó szerint begépelt interjúkat a Vajda Júlia és Kovács Éva (2002) által leírt módszertani elvek mentén elemeztem. Először kigyüjtöttem a biográfiai adatokat - azokat a jól adatolt eseményeket, amelyeket valamilyen összehasonlítás mentén el tudtam helyezni az életútban időrendi sorrendben. A biográfiai elemzést követően a szöveget szekvenciákra bontottam, és hermeneutikai elemzéssel ${ }^{3}$ haladtam szekvenciáról szekvenciára; hipotéziseket állítva, illetve azokat megcáfolva tettem kísérletet a megélt és az elbeszélt élettörténet különválasztására a sportnak a narratívát felállító cselekvő életében betöltött szerepével kapcsolatban.

Amikor kiválasztottam az alanyaimat, semmit nem tudtam róluk. Az interjúk során vált nyilvánvalóvá, hogy az életük egy szakaszában mindannyian súlyos testkép- és/vagy evészavarral küzdöttek. Ez nagymértékben átírta a fejemben lévő elemzési elképzeléseket, és erőteljesebb fókuszra kényszerített a családi dinamikák, a pszichés elakadások, illetve a lehetséges lelki eredetű okok feltérképezésének területén, mint arra előzetesen számítottam.

2 Mármint ami a célját illeti. Ami nem más, mint az „egész-ség érzetének” kialakítása.

3 A hermeneutikai esetrekonstrukció során a szekvencia-, illetve biográfiaelemzésben verifikálható és falszifikálható hipotéziseket állítok fel a feldolgozott szövegrészek után, majd ezeket a további tartalmi megismerés eredményeinek függvényében megtartom vagy elvetem. 
Mindemellett igyekeztem nem átlendülni olyan számomra ismeretlen tudományterületre, ahol az általam megfogalmazott hipotézisek vagy állítások elvesztenék hitelességüket, illetve tudományos alapjukat. Mindazonáltal elengedhetetlennek tartottam, hogy elvégezzem ezt a mikroelemzést, és csak utána térjek rá a szükebb értelemben vett szociológiai vizsgálatra, ugyanis azt gondolom, ez a kettő nem elválasztható abban az elméleti keretben, amelyben az általam vizsgált kutatási tárgyat elhelyeztem. Nem tudtam minden aspektusát kifejteni a feltárt sejtéseknek, így szürnöm kellett, hogy mi az, amit megosztok a dolgozatomban, mivel túlságosan is szerteágazó volt, amit találtam, és néhány helyen valóban elhúzott olyan lélektani mélységekbe, ahol a felállított hipotéziseimnél azt éreztem, hogy ezek az állítások meghaladják a pszichológiai ismereteimet ahhoz, hogy kellő önbizalommal és hitelességgel vállalkozzak azok interpretációjára. Így szigorúan azokat az elemeket emeletem ki, amelyek a test érzékeléséhez és a sport szerepéhez köthetők az adatközlők életében, és ez egyéb dinamikák ebben a dolgozatban nem, vagy csak érintőlegesen lettek kifejtve.

\section{Zsófi életútja}

Zsófi (21) elbeszélt életútjának biográfiai elemzéséből kirajzolódik, hogy egy erősen ambivalens viszony füzi a szüleihez - különösen az apával meglévő feszültség az, ami át- meg átszövi még a száraznak tartott életrajzi adatokat is. A döntések mögött folyamatosan felsejlik az ellenállás-meghajlás dichotómiája, meghatározó strukturáló elem az ebből következő feszültség, illetve az ennek feloldási kísérleteiből fakadó cselekmények. Zsófi egy vidéki kistelepülésen született, az édesanya a segítő szakmában dolgozik, az édesapa pedig meghatározó vállalkozója, erős embere a közösségnek. Hárman vannak testvérek, egy nővére és egy öccse van, mindkét testvér esetében erős hangsúlyt kap az apának imponáló müszaki, reálvégzettség, szemben Zsófi humán, a segítő szakma felé való orientációjával. Mivel Zsófi második gyerekként születik, jóval a nővére után, de nem sokkal az öccse előtt, ezért alapélménye az egyedüllét, és az érzés, hogy nem számíthat a szülői törődésre. Egyrészt lány, másrészt középső gyerek. A nővér idősebb, és bár ő is a segítő irányba indult a felsőoktatásban, később „javított”, és reálterületen folytatta tanulmányait és ott is helyezkedett el, Zsófi szerint kiharcolva ezzel az apa elismerését. Míg az öccse - valamiféle patriarchális, törzsi gondolat mentén, már csak a biológiai neméből kifolyólag is - megkapta születésétől fogva mindazt az elismerést, amiért Zsófinak keményen meg kellett küzdenie. Ezek az általa sokszor sziszifuszinak megélt küzdelmek folyamatos feszültséget generáltak benne már egészen kisgyerek korától fogva, az értéktelenség és elveszettség érzése, illetve az elhagyatottságtól, elhagyástól való félelem az életrajzi struktúra adatolásában is megjelenik. Négyéves, amikor elveszíti anyai nagyanyját. Először szembesül a halállal, egy olyan rokon halálával, aki az apához köthető, körülbelül ugyanakkor, amikor megszületik az öccse, vagyis van egy negatív indulatátvitel mind az öccse, mind pedig az apja irányába. És ekkor meghal a nagymama. Ez lehet egy olyan, a fejlődési szakasz mágikus gondolkodására épülö önhibáztatás, illetve feszültség alapja, amely a későbbi szülőhaláltól való rettegéshez vezethet. Illetve, hogy az ilyen irányú emóciók rosszak, pusztítók, nem verbalizálhatók. Így ez a feszültség a legkisebb ellenállás törvénye alapján valamilyen úton-módon kiutat fog keresni magának. Ez lehet alapja az autoagresszió különböző formáinak, a zárkózottságnak, a harcra, a megküzdésre való képtelenségnek. Jól adatoltak az apával való minőségi együttlétek, ugyanakkor alig van belőlük 
néhány, és akkor sincs egy kettőjük közt létrejövő közös élmény, mindig meg kell osztani valakivel (az öccsével), ezen alkalmak során az apa megnő, hős lesz, titkok tudója, sárkányok legyőzője, aki erősebb az egész világnál, aki csak azt tiszteli, aki szintén olyan erős, mint ö.

Nyolc-kilenc évesen már együtt edzenek az apával. Játékos, tét nélküli dolognak írja le az akadályokkal való megküzdést, ugyanakkor az elbeszélésben nincs helye a feladásnak, és elismerés csak akkor jár, ha megtörténik a „léc megugrása”. Fontos bevésődése ez annak, hogy az egyetlen dolog, amivel az apa szeretete és elismerése, ezáltal az „énség” megteremtése megtörténhet, az a fizikum megjelenítése, illetve az azzal való manipuláció. E mentén kaphat figyelmet, ezáltal lehet versenyképes a három gyerek között elosztandó, szükösre szabott szeretetporciókért folytatott harcban. Az anya egy látszólag gyors lefolyású, komolyabb panaszokkal nem járó gyengesége krónikus betegséggé válik, amely során rendszeresek a roszszullétek. Zsófi szülőelvesztéstől való félelme olyan áttétet kap, ami óriási szorongást generál benne, ugyanakkor nincs kivel megbeszélnie. Az apa nem ad válaszokat. A gyerek egyedül marad a félelmeivel, ebben Zsófi nem lehet partner. Visszaigazolja a manipulációképtelenséget, hogy a világ az akarata ellenére dobálja ide-oda, hogy a kérés, a könyörgés nem elég. Sem ahhoz, hogy megnyugtassa, sem ahhoz, hogy vele maradjon az apa. Rengeteget dolgozik, sokat van távol, míg az anya egyedül viszi a háztartást, dolgozik mellette, gyereket nevel. Olyan életmód, ami folytonos küzdelmet jelent, ha nő vagy, és folyamatos föhajtást az erős férfi elött. A kommunikáció nem segít, a verbálissá tett emocionális szorongás nem opció, nincs rá válasz, se szeretet, sem megértés. Ugyanakkor fontos biográfiai fordulópont, amikor az anya választás elé állítja az apát, hogy vagy a munka, vagy pedig a gyerekei és a családja. Az apa a családot választja. Ez olyan aktus imprintingje lehet, olyan megküzdési minta, amely alapja lehet a lázadásnak, az önformáláshoz való jog kikövetelésének.

A szülők vallásosak - igaz, ez a vallásosság nem jelenti az élet minden részére kiterjedő mély megélését a hitnek, de kulturálisan és hagyományaikban őrzik a keresztény külsőségeket. Zsófit vallásos óvodába és iskolába íratják, nagyobb ünnepekkor templomba mennek, és a papot alkalmanként kérik, hogy egy-egy elhunyt hozzátartozójuknak ajánlja a misét. De a vallásosság a meghatározó pillanatokban nem jelenik meg mint rendező elv, utat mutató imperatívusz. Egy újabb fenyegető árnyék megjelenésekor - egy hozzátartozó, a nagypapa lehetséges elvesztése során - megint nincs kapaszkodó. Általános a pánik, hogy most mi lesz, de ezt is inkább csak érezni lehet, passzívan befogadni, de nem kiadni, hozzátenni az érzéseit. Ekkor jelenik meg a nővér mint potens aktor az élettörténetben, és megnyugtató válaszokat ad. Az első olyan személy, aki konkrétan, adatolt eseményhez köthetően segítséget nyújt és biztos érzelmi viszonyítási pontként jelenik meg. A vallásos óvoda után vallásos iskola következik, ahol folyamatosan próbálják valamilyen sportra beíratni, de csapatsportokba, ami nagyon nem megy Zsófinak. Ügyetlennek érzi magát, nem komfortos a helyzet, amiben van. Ráadásul ezek nem csak egyszerű sportolói sikertelenségek, hanem minden egyes bukás egyben lehetőség is arra, hogy izolálódjon a közösségből, valamint hogy elveszítse az így is csak ritkán rávetülö, bátorító apai tekintetet. Talán ebből is fakadhat az az áldozatszerep, amibe belekényszerítik a kortársai: kiskamaszként folyamatos zaklatásnak van kitéve az iskolában. Ez olyan mértékig fokozódik, hogy megjelenik az életrajzban a legszélsőségesebb autoagresszió, az öngyilkosság gondolata. És sehol egy felnőtt, sehol egy olyan referenciaszemély, akihez fordulhatna. Szinte természetes, hogy egy ilyen rideg, és az ő bánatára reflektálni képtelen világ elől visszavonulót fúj az egyetlen olyan terrénumra, ahol ő a legkompetensebb személy: a saját testébe. Megkezdődnek az evészavarok. A középiskola 
nem hoz megújulást, mivel a bántalmazó lány szintén ugyanoda jelentkezik. Az a bizonyos schrödingeri doboz egy ideig végtelen mennyiségü cselekvési alternatívát hordoz magában, amelyek között az eddig elmondottak alapján kiemelt helyen találjuk az önpusztítás különböző formáit: falcolás, promiszkuitás, evészavar, öngyilkosság - teljes behódolás a bántalmazónak. Ám Zsófi, a maga módján, egy egészen új, nem várt megküzdésmódot választ, és felveszi a harcot.

Eldönti, hogy lefogy - de nem az éhezést választja, hanem sportolni kezd. Futni. Ezzel egy időben az életének más területein is megpróbál kompetens szereplővé válni, először szegül szembe az apai autoritással, de az apa nem tudja felülírni a megszokott mintákat. Megbeszélhetnék, reflektált tudássá válhatna Zsófi élménye és kritikája, de nem így történik, és ez az opponálás érezhetően megrontja a kapcsolatukat. Ez a tulajdonképpeni kamaszkori újjászületés rögtön azzal az élménnyel társul, hogy az első szava, kifejezése - a „Máshogy szeretném!" - rögtön szeretetmegvonással jár. A futás már nem elég, elkezd konditerembe is járni. Két éve edz folyamatosan, amikor bejelenti, hogy nem fog többet a szülőkkel templomba menni, mert hazugságnak tartja a papság és az egyház intézményét, és nem gondolja, hogy az intézményesült kereteknek kéne az ő hitét meghatározniuk. E mögött lehet egy olyan általános kritika is a családdal szemben, hogy kifelé látszólag idilli képet kell mutatni, meghintve hazug szakralitással, miközben valójában senki nem veszi észre, hogy őbenne mi zajlik.

Az első barátja egy testékszereket hordó fiú, akit a szülők nem tudnak elfogadni a kinézete miatt, nem tart sokáig a kapcsolat, de fontos élmény, hogy nem konzisztens a fenntartott homlokzat és a cselekvés közötti kapcsolat. Szavakban az ember belső értéke a fontos, egészen addig, amíg meg nem jelenik a küszöbön valaki, akinél tényleg mélyfúrás kéne, hogy túllássunk a kérgen. Úgy dönt, hogy ő megpróbál megfelelni az ideálnak. Beköszönt a nagy szerelem, aki látszólag nem képes úgy érezni és kötődni, ahogy Zsófinak jó lenne, de ennek ellenére kitart mellette. Majd meggyógyítja, mert azt gondolja, ő az igazi. Amikor a fiú telefonon közli vele, hogy vége, teljesen összeomlik. Vigasztalhatatlan. Az életrajz eddigi adataiból teljesen adekvát válasz lenne, ha megjelenne a súlyos autoagresszió valamilyen formája, az öngyilkosság gondolatával való eljátszás, kísérlet. Ehelyett a sportba menekül. Életének ezen a pontján én ezt a sportolási rutint már maladaptívnak minősítem, mivel a Demetrovics (2012) által leírt sajátosságok mentén arra lehet következtetni, hogy fennáll a függőség kialakulásának lehetősége. Ez is autoagresszió, igaz, hogy társadalmilag pozitív elbírálásban részesül és nem stigmatizált, de attól még az. Heti hat napon keresztül napi 10 kilométert fut, egészen addig, amíg tetemes mennyiségű fájdalomcsillapító bevétele nélkül már nem is tud kikelni az ágyból. Az orvos súlyos csonthártyagyulladást állapít meg. Zsófi a futást abbahagyja, de a súlyzós edzést folytatja, azonban most már sokkal nagyobb intenzitással. Innentől datálja a súlyos testképzavar kialakulását, a bulimia kezdetét. Megjelenik a kényszerképzet, miszerint a szerelme azért hagyta el, mert nem volt elég jó, nem volt elég vékony, nem volt elég szép.

A középiskola végén eldönti, hogy segítő szakmát választ, és egy vidéki nagyvárosba szeretne menni tanulni. Az apa ellenzi: „Ezért a szakért minek oda menni?” Ö azonban nem enged, és jelentkezik. Az apa annak ellenére, hogy nem ért vele egyet, anyagilag támogatja. A szülői háztól való leválást saját újradefiniálása, felnőtté válása szempontjából is fontos mérföldkőnek tartja, de az apától való függés és a neki való megfelelési kényszer nem hogy csökkent, de még nőhetett is abban az időben. Nem segített a helyzeten, hogy összeköltözött egy nagyon vékony lánnyal, akinek a jelenléte már önmagában versenyhelyzetet teremtett 
számára. Folyamatosan hasonlítgatja magát hozzá, azt érzi, hogy soha nem lehet olyan jó (értsd: vékony), mint ő, de mindent meg kell érte tennie, hogy legalább megközelítse az áhított állapotot. Ezek a külső okok hozzájárulhattak ahhoz, hogy tovább mélyítsék a szenvedését és rombolják az énképét. Szinte egyáltalán nem eszik, lefogy 44 kilóra, miközben napi rendszerességgel végez nagy intenzitású, szabadsúlyos erőnléti gyakorlatokat. Egy edző felfigyel rá, de nem a „kóros fogyásra”, hanem a kitartó munkára, és felajánlja neki, hogy induljon versenyen fitneszmodell-kategóriában, amihez viszont versenyétrendet kell tartani, ami rendkívül spártai. Ez két dolgot jelent: egyrészt az edző meghívása benyom egy „jutalmazó gombot", hiszen elismerik azt, amit csinál, igaz, ez megint az a fajta elismerés, amit az apjától kapott, pont ezért ismerős és komfortosan mozog benne, másrészről pedig legitim narratívát kölcsönöz annak, hogy miért nem eszik. Versenyre készül, lehet nem enni.

Mindeközben rövid, átmeneti kapcsolatokba menekül. Így próbál szeretet kicsikarni a környezetétől, de minden partnere elhagyja. Őket hibáztatja, amiért folyton átverik. Megtörténik az első önhánytatás. Senkinek nem tűnik fel, senki nem szól, hogy le kéne állnia. Azt érzi, hogy óriási fegyver van a kezében, bármennyit ehet, nem fog hízni, hiszen csak kihányja, és meg van oldva a dolog. Rendszeressé válnak az ájulások és a rosszullétek. Az edzések intenzitását, azok számát, illetve a konstans táplálékhiányt nem bírja a szervezete. Az érzelmi instabilitás és a leromló fizikum könnyen tragédiába torkollhatna, ám a reziliencia egy nem várt eszközéhez nyúl. Nem kér segítséget orvostól, edzőtől, családtól, hanem egyedül jön rá, hogy ez komoly dolog. Kialakul a betegségtudat. Saját magát diagnosztizálja súlyos testkép- és evészavarral, valamint testedzésfüggőséggel. Hamar rádöbben, hogy egyedül mégsem fog menni a gyógyulás, megpróbál beszélni az anyjával. Az anya összeomlik, Zsófi eldönti, hogy többet nem szól neki, nem akarja, hogy azt érezze, rossz anya volt, hogy magát hibáztassa. A nővéréhez fordul, aki már bizonyította, hogy képes akut helyzetekben támaszt nyújtani: nem is kell csalódnia. A nővére maximálisan megérti és támogatja mindenben. Nem ítélkezik. Az ő érzelmi támogatásával és jelenlétével az anya is megtalálja a kompetenciáit. Elküldik a lányt egy speciális klinikára, ott azonban olyan hosszú a várólista, hogy komolyan fennáll a veszélye a súlyos állapotromlásnak, ezért pénzt nem sajnálva magánterapeutát választanak Zsófinak. De itt meg is áll a történet azon része, ami megteremtené a közös megküzdés élményének lehetőségét. Mind az apa, mind az anya vállalják a teljes anyagi fedezetét a kezelésnek, de érzelmileg nincsenek Zsófi mellett, egyedül kell szembenéznie az állapotával. A terapeutával könnyen bizalmi kapcsolatot alakít ki, mivel ő is fut, így úgy érzi, hogy könnyebben tud nyitni az irányába, és nagyobb megértéssel fordul a problémája felé. Elkezd egy olyan csoportba is járni, ahol hasonló tünetegyüttessel küzdő emberek gyülnek össze. Az okok többnyire családon belüli szexuális abúzus, valamilyen gyerekkori trauma, a családi müködés dinamikájának olyan sajátossága, ami az azt elszenvedő alanyt ebbe a típusú autoagresszív elaborációs mintába kényszeríti. A csoportmunka lehetőséget ad arra, hogy reflektáljon a saját helyzetére, a többiekkel való összehasonlítás során úgy érzi, hogy sokkal jobb helyzetben van, és nagyobb esélye van a gyógyulásra, mint sokuknak a csoportban. Kiemelt momentumként említi meg, amikor azt a feladatot kapják, hogy valamilyen módon jelenítsék meg az általuk elképzelt elvarázsolt családot, és amíg a legtöbben ezt a feladatot úgy értelmezik, hogy rajzolják le az ideális családot, addig ő valóban egy elvarázsolt családot rajzol le, ahol egyedül ő jelenik meg humanoid létezőként. Ezt úgy értelmezi, hogy a családja nélkül ő nem egész, és nem is tudna létezni. Ennek ellenére, ugyanakkor az eddig elmondottakból maximálisan levezethetően, a családot nem vonják be a terápiás folyamatba. Arról 
nem mond semmit, hogy lett volna-e ilyen irányú intenció, de azt megemlíti, hogy a család bevonódása nélkül igazából nem feloldható az ok, ami kiváltotta a panaszait.

Az állapota javulni kezd, újrakezdi a sportot, de elhagyja a konditermi edzést és a futást is, tiszta lappal indul. A saját testsúlyos utcai edzés felé fordul. Önmagát oktatja, utánaolvas, képzi magát. Egyfajta újradefiniálás ez is, hiszen bár sportol, de nem tér vissza a régi megszokásokhoz, igyekszik új alapokat lefektetni. Nem javul a kapcsolata az apjával, és úgy általában a családjával sem. Egy lakodalomban számonkérik rajta, hogy sokat ivott, és egy hétig nem szólnak hozzá. Tetováltat és piercinget is rakat be magának, de csak a piercingről tudnak a szülők, a tetoválást nem lehet nekik elmondani, mert „kiakadnának”. Egy nyarat pultozik. Ez több szempontból is fontos: egyrészt, az apja felhívja telefonon, és egy órát beszélnek - állítása szerint egész életében nem beszélgettek egyhuzamban ennyit -; másrészt a szülőfalujában a falusiak elhíresztelik róla, hogy prostituált lett. Az elsőt annak tudja be, hogy az apja várja, mikor fog elbukni, a másikat pedig a falusi lét számlájára írja. Egyáltalán nem akar hazaköltözni, és azt érzi, hogy mások véleménye már nem kell, hogy befolyással legyen rá. Azt érzi, kezd „gyógyulni”. Másfél év után ő szakít a barátjával, mert az más lányokkal flörtöl. Azt gondolja, hogy a fiú gátolná őt a fejlödésben, és neki nem feladata megmenteni senkit. Rögtön leviszi az új barátját egy családi rendezvényre, a szülők nehezményezik, hogy odahozta, mikor még alig ismeri, és épphogy kilépett a régi kapcsolatból. Talán az átélt szenvedés és a halállal kapcsolatos saját élmények miatt, de elhelyezkedik egy olyan alapítványnál gyakornokként, ahol súlyosan beteg, haldokló emberekkel foglalkoznak, de nem akar segítőként dolgozni. Vállalkozó lesz, és keményen beleveti magát a pénzügyi világba. Nem lehet elengedni a gondolatot, hogy még mindig az apja előtti bizonyítási vágy a domináns hajtóerő, bár most már megjelenik az anya által végigjárt életút tagadása is. 21 éves korára az emésztőrendszere és a gyomra tönkrement, de az interjú készítésekor azt érzi, hogy lelkileg jól van, és erősebben jött ki ebből a küzdelemből, mint ahogy belépett.

\section{Az identitáskonstrukció útvesztői}

A biográfiai elemzés eseménytörténetét „finomítom” a szekvenciaelemzésekkel. A felállított hipotézisek és a lehetséges cselekvési alternatívák, illetve választott stratégiák mentén kirajzolódik egy mintázat, hogy pontosan milyen szerepet tölthetett be a sport az identitás meghatározásában, az ontológiai biztonság megteremtésében. Úgy gondolom, hogy az elemzés szempontjából az elmesélt élmények valóságtartalmát, az érzelmek valóságosságát nem tisztem kétségbe vonni, hiszen ha az interjúalany úgy érezte, akkor az úgy is volt. Legalábbis az ő valóságában, és most ezzel az egy valósággal dolgozom. A felvázolt alternatívák és hipotézisek esetében olyan mintázatokra mutatok rá, amelyek organikusan következhetnek az elmesélt élettörténetből, és elmondanak valamit a megéltből, ami talán nem tud úgy „elmesélődni”, ahogy az megtörtént, mivel a standard történetmesélési keretek, amelyeket magukévá tesz az adott kultúrában élö, hozzáigazítják a megtörtént eseményeket az elfogadott narratívakerethez. Nagyon erős az interjúban, rögtön az elején feltünik és kihangsúlyozásra kerül, hogy Zsófi nem fiú és hogy középső gyerek. Ez egy olyan patriarchális alapon szerveződő családmodellt feltételez, ahol a nő csökkent értékü, ahol csak azért, mert valaki lány, már nem is lehet értékes. És ha az elsőszülöttségre vagy épp a legkisebbnek kijáró kiemelt figyelemre nem jogosult a gyerek, akkor nem kaphat annyi szeretetet és törődést, amennyit igényelne. 
Hát ő elég, ez lehet, hogy erős kifejezés rá, ezt lehet, hogy korábban is mondtam, ő elég hímsoviniszta. Tehát ő nagyon, nagyon... Nőként nagyon nehéz érvényesülni az ő szemében, vagy hogy' mondjam, így értékesnek lenni.

Az apa mindenható a családban. Alfa és ómega. Zsófi számára is folyamatos viszonyítási alap és vonatkoztatási pont: minden játszma tétje az ő szeretetének megszerzése. Az ő elismerése minden későbbi elismerés alapja lesz, mindent ehhez fog hasonlítani. Ha az apa szemében a nő nem elég értékes, akkor Zsófi valószínűleg ebből nem azt szűri le, hogy ez csak az apám véleménye, és nem objektivált valóság, és nem mond el semmit az én értékemröl, hanem belsővé teszi az értéktelenség érzését.

(...) ilyen sportosan nevelt minket, ilyen mozogni, meg kötelet másztunk meg egy csomó minden, amit egy átlagos kislány nem csinál, és tudtam, hogy az az egyik olyan, ha nem is, de talán az egyetlen, amiben kaptam valami szintü elismerést. De ez is nagyon picit mondható elismerésnek, és nagyon... Tehát megdicsért valamiért (...).

Az egyetlen terrénum, ahol Zsófi kompetensnek érezhette magát és elég jónak az odafigyelésre, az a fizikai teljesítmény területe - ha jól teljesített, ha erős volt. Ez már alapból bekódolhat egy „torz képet” a mozgásról, egy olyan jutalomvezérelt motivációs mintát, ahol akkor vagyok jó és szerethető, ha jó a fizikumom, ha jól nézek ki és erős vagyok.

(...) amikor 14 éves voltam, nyolcadikba jártam általánosba, akkor volt ott egy lány, aki engem valamiért nagyon nem szeretett, (...) Ez az ilyen klasszikus, mint az ilyen amerikai filmekben, azok a gyerekek, akik öngyilkosságba menekülnek, mert az iskolában pokollá teszik az életüket, na, ez voltam én.

Hogy ez megtörténhetett, és a gyermek nem kapott semmilyen segítséget; hogy egyetlen felnőtt sem állt mellé - se a szülők, sem a tanárok -, óriási stressz lehetett, amit az evéssel próbált kompenzálni. Mindemellett keveset mozgott, mivel az általános iskolában elment teljesen a kedve a sporttól a sok rossz élmény miatt, és a két dolog kombinációja óhatatlanul elhízáshoz, ez pedig további abúzushoz vezetett a kortársak részéről.

(...) megutáltatták velem a sportot, mert mindig olyan helyekre vittek a suliból és anya is olyan helyekre íratott be, pont azért, mert nem is tudtam elmondani neki, hogy ezt nem akarom. Ilyen csapat, csapatos sportokba, és mindig én voltam a legkisebb, és nem mertem kinyitni a számat, meg minden, és ezek pokoli élmények voltak.

Emellé párosult egy erős szülői kontroll az evéssel kapcsolatban: jelesül, az anya nagyon odafigyelt arra, hogy egészségesen étkezzenek, ami önmagában nem probléma, de egy olyan családi közegben, ahol egyébként is nyomasztó, bár nem kimondott alá-fölé rendelődések lehetnek, ahol a gyerek azt érezheti, hogy nem tud beszélni a problémáiról, ott egy ilyen szigorú fiziológiai szükségletet kontrolláló elvárás okozhat szégyenérzetet. Akkor, amikor a gyerek egy másik traumát próbál ezzel feldolgozni, mivel nincs lehetősége más úton csökkenteni a feszültséget, ez csak még inkább izolálhatja őt, és büntudatot okozhat. A szekvenciaelemzés során számos alkalommal az adekvát válasz, illetve a „logikus folytatás” valamilyen autoagresszív cselekedet lehetett volna, de minden alkalommal, amikor én azt a hipotézist állítottam fel, hogy a különböző cselekvési alternatívák között kiemelt helyet foglal majd el az öngyilkos gondolat, vagy valamilyen addiktív, dependens megküzdés, akkor mindig belépett a sport mint „mentőöv”. 
Itt is, amikor gyakorlatilag sorozatos iskolai abúzusról és érzelmi nyomorgatásról számol be, bár a segítségkérés vagy az önbántás adekvát reakció lenne, ő mégis a harcot választja. És bár nyíltan nem konfrontálódik, de olyan pajzsot emel maga elé, amivel szembe tud szállni a támadásokkal, illetve amit az agresszorok nem tudnak átütni.

Úristen, öt kilométer, és akkor eljött a bűvös 10. Hogy 10 kilométert le tudok futni, és akkor folyamatosan éreztem, hogy ööö, tehát a családunkban senki nem fut. Egy ember van, de ő ilyen távoli rokon, aki így fut, de ő így katona meg férfi, meg idősebb meg minden, tehát az más. És akkor éreztem valahol ezt az elismerést.

De a futás, a testedzés nem csak a harc eszköze lett a külső támadókkal szemben, hanem a családon belüli szeretetért és odafigyelésért vívott küzdelemben is új lehetőségeket nyitott meg.

Tehát az, hogy ő elismerte azt, hogy én ezt csinálom, hogy futok, meg hogy „úristen, mennyit?!”. Ezzel, hogy ő meg volt ijedve, hogy ő mennyit futott, meg mit tudom én, ez nekem jó volt. Ez motivált. Úgy voltam vele, hogy aggódjatok csak értem.

Az aggodalom, az, hogy az anya elkezdte irracionálisnak látni a sportolást és a gyerekére veszélyesnek, olyan helyzetet teremthetett, amin keresztül elképzelése szerint lehetségessé vált hatni az apára is. De azért már látszik, hogy ez sajnos több, és messzebbre visz. A sport nem nyúlt hozzá a mély struktúrákhoz, nem változtatta meg az alapvető személyiségjegyeket, holott az látszik, hogy ezért kezdte el használni és ezért is folytatta, majd vetette bele magát egyre mélyebben.

Mert, hogy ha nem, akkor meg fogok megint hízni, és biztosan ez a csávó is azért hagyott el, mert nem voltam neki elég jó, és akkor itt kezdődött ez a testképtorzulás. Itt igazából.

A krízisek regresszióba taszítják (a fenti idézet az akkor igazinak tartott fiúval való szakítás utáni állapotot tükrözi), ahol újra szembesül azzal a képzettel, hogy ő nem szerethető, csak ha jó fizikumú, és biztos nem volt elég jó, de ha jobban, keményebben dolgozik, akkor megkapja azt az odafigyelést és elismerést, amiért annyit tett már eddig is, de mégis olyan kevés eredménnyel járt.

És akkor nyilván úgy voltam, hogy „úristen, hogy lehet ez?!”, hogy valaki meglátott bennem valamit. Főleg úgy, hogy én semmit nem is tudok edzeni igazából.

Az egyetemi évek elején, amikor találkozik egy edzővel, ez az elismerés iránti igény taszítja a még nagyobb önkizsákmányolás és önsanyargatás felé. Nem tudja úgy kezelni a felajánlott versenylehetőséget, mint egy jogos elismerését a munkájának, mert az az önszeretet egy olyan fokát feltételezné, amire akkor még nem képes: egy ilyen jellegű önelfogadás egyszerüen nem opció. Csak a meglepődés lehet adekvát válasz: ez velem hogyan történhet meg? Hogy valaki értékesnek talál? Nem beszélt az edzőnek a problémájáról, ami nem meglepő. Maga a kommunikáció önmagában, az emóciók megjelenítésének lehetősége csak rendkívül szűkre szabott keretet kapott az életében, még az olyan, elvileg hozzá közel álló emberekkel is, mint a családtagjai. Egyszerüen nem volt bevett feszültségoldó eszköz, így nem is fordulhatott hozzá segítségért. Még akkor sem, amikor találkozott egy olyan tekintélyszeméllyel, aki talán adhatott volna tanácsot. 
(...) nekünk mindig azt mondták a szüleink, föleg anya, hogy mi azért vagyunk egy család, hogy mindent megbeszéljünk, de közben ők soha nem mondtak nekünk semmit. (...) Meg láttuk azt, hogy baj van? Nincs, nincs, és akkor láttuk azt, hogy tök szomorúak. A gyerek ilyenkor mit érez? Azt, hogy énvelem van baj. És akkor is ez volt. És tudtam, hogy látják, illetve egy ideig hitegettem magamat azzal, hogy ők nem tudnak erről semmit, de hát közbe meg tudtam, hogy látják, és nem, senki nem beszélt erről. Senki.

Többször is előjön az interjú során ez a kettős beszéd. Egyrészről van a társadalmi normák által normálisnak és elfogadottnak tartott kommunikációs sémák alkalmazása, és egyáltalán, a család idealizált képe, aminek folyamatosan igyekeznek megfelelni, de közben a gyerekek azt érzik, legalábbis Zsófi biztosan, hogy ez nem igaz, hogy ez hamis. Hogy valami titok lappang a mélyben, amiről nem lehet beszélni. Ahogy az interjúrészletből is látszik, ennek nem is kell átütő erejü, világraszóló botránynak lenni, elég az is, ha a gyerek azt érzi, hogy valami baj van, és máris belsővé teszi az érzést, miszerint vele van a baj. Ez Zsófi esetében a sportba lett átültetve, és óriási elörelépés, amikor hosszas terápiás munka után vissza mer lépni a pályára, de már tudatosan, reflektáltan, a vele történt eseményekre, illetve az általuk generált érzésekre fókuszálva. Hogy ne a megfelelési kényszer vezesse, hanem csak az, amit egyébként legtöbben az amatőr sporthoz kötünk - hogy érezze jól magát.

Akkor annyira jó volt az, hogy érezni, hogy nem úgy van, mint régen, hogy jól van, most ezt a kötelezőt letudtam, és holnap muszáj mennem újra, vagy mondjuk este muszáj megint mennem újra, hanem hogy úgy kellemesen elfáradtam.

És itt nem csak arról van szó, hogy a sporttal kapcsolatban jelenleg helyre van állítva egy olyan egyensúly, ami lehetőséget ad számára a mindennapi életben való funkcionálásra, hanem az is fontos, hogy ez a hanyatlás- és pusztulásnarratíva hogyan változott át hősies küzdelemmé, ami bár sok kihívást tartogatott, de mégis megérte, mert ezáltal Zsófi többé vált a végére.

Sokáig úgy éreztem, hogy tönkretettem az életemet kb., hogy ez az egész betegség... Most már, úgymond, hátrányban vagyok. Meg hogy ez az egész bárcsak ne lett volna, miért pont velem történik. És most meg már ott tartok, hogy köszönöm azt, hogy ez megtörtént.

\section{Egyedivé vált társadalom}

A személyes változások nyomon követése után szociológiai vizsgálódásom fókuszát az egyén újradefiniálására, megformálására, identitásgenezisére irányítom. Egy olyan korban, ahol a változás gyakorlatilag állandó, az iránytű folyamatosan saját tengelye körül pörög, és ami az egyik cselekvőnek észak, az a másiknak dél, és ugyanolyan valid mindkét állítás, sokféle lehet a produktív élet végcélja, ahogy a produktív élet elbukása is. És a produktivitás, illetve a bukás fogalmai is folyamatosan helyet cserélhetnek ezen a zakatoló hullámvasúton, ahol az objektív, univerzális igazság keresése visszaszorult az irracionalitásként megbélyegzett marginalitás világába. De a bizonytalanság „csak” az egyénben lecsapódó impressziók leírására alkalmas, és nem eliminál egyik pillanatról a másikra éveken keresztül alakuló strukturális hatásokat, illetve ha ezek fel is bomlanak vagy látszólag átadják a helyüket valami újnak, 
attól még a megküzdési stratégiák, az egyéni döntések, választások és lehetőségek nagyon is hatnak. Olyan örökség ez, ami - ha nem is tudatosan, de - meghatározhatja, hogy merre van az észak és merre a dél. A nagyon személyes érzelmi szint, egy család bánata és öröme, egy gyerek, egy anya és egy apa pozíciója, bár egy szinten egyéni döntések sorozatának következménye, de egy másik szinten társadalmi folyamatok aggregátuma is. Éppen ezért fontosnak tartom, hogy megkeressük az egyénivé vált társadalomban, a látszólag partikuláris élményben, az általánosról látszólag semmit el nem mondó egyéni történetben a nagy társadalmi folyam által okozott változásokat és nyomokat.

Interjúalanyom falusi környezetből származik, egy különösen leszakadónak számító régióból, ez akár előre is vetíthetné, hogy meghatározó lesz az életében a társadalmi háttér, az osztály, illetve Magyarország esetében a vidéket sokszor jellemző, már-már rendi struktúra (Szabó 1991). Ugyanakkor ez nagyon ritkán jelenik meg az elbeszélt történetben. Zsófi esetében a család egyáltalán nem követte a leszakadó, többnyire aprófalvas régiókra jellemző modellt. Bár a „genogram” nem túl átfogó, és az élettörténet, valamint a családi narratíva nem, vagy csak kis mértékben nyúlik túl a szülőkön, de nem találunk arra utaló jelet, hogy Zsófi esetében a családi életstratégia felolvasztásáról lenne szó. Ami évekig tetszhalott állapotban volt, arra várva, hogy a megfelelő lehetőségek együttállása esetén működésbe léphessen.

Egyszer volt egy olyan névtelen feljelentés, hogy apám, vagy hogy mi, egy park közepén lakunk, egy villában. Na most ez egy 130 vagy $200 \mathrm{~nm}$-es ház, vagy annyi sincs, 180. Tök átlag berendezéssel. Jó, nagy telkünk van, apa (...). Imádja a fákat, növényeket. Anyám kertészkedik, virágokat ültet, tényleg nagyon sok növényünk van, minden. Meg nem is lehet belátni, mert kőfal van, de nem ilyen magas. De annyira irigyek az emberek, hogy feljelentettek.

A fenti idézet is annak lehet bizonyítéka, hogy egyáltalán nem illeszkedik bele a közösség által elvárt vagy megszokott keretekbe az életmód és a „sikeresség” család által preferált és elért módja, szintje. De ezzel kapcsolatban nem csak a család egészét, hanem az egyént is érheti kritika.

És ahogy elkerültem, a világ így elkezdett kinyílni. Elkezdtem nőiesebb ruhákban járni, magassarkú, stb. És akkor hallottam még utána is tőle, hogy én kurva lettem - én, ilyen lettem, olyan lettem. És akkor még bántott egy kicsit, úgy zavart.

Ahogy megtörténik a normaszegés, rögtön jön a szankció a közösség részéről. És itt nem is biztos, hogy a ruha és az öltözködés megváltozása a fontos, hanem az, hogy elment. Hogy olyan cselekvési alternatívát valósított meg, ami eltér a megszokottól. Mind családi, mind pedig egyéni szinten is az „idegen” (Biczó 2004) problematikájával szembesülünk. Az idegen jelenléte szembesíti az addig izoláltan létező közösséget a külső világ létezésével, ami adaptív, emancipatorikus megküzdés esetén nyitottsággal és kíváncsisággal fordul az új felé. Úgy tűnik azonban, hogy ez a magyar vidék esetében kevésbe opció, így egy elutasító, az ismeretlenben nem a miénkhez hozzáadni képes, hanem az igazságunkat, és ezzel minket is illegitimmé tevő aktort látnak. És az nem számít, hogy Zsófi ott született, hiszen szimbólumaikban, életstílusukban ő is és a családja is elhatárolódnak, kitagozódnak a közösségből. Ugyanakkor ez a reakció - bár nyomasztó, ha a családot érinti, de - nem jelenti azt, hogy nem egy olyan, a közösség és a struktúra által az egyén számára belsővé tett mintáról van szó, ami bennük ne lenne meg, és ne használnák az őket körülvevő jelenségek klasszifikációjakor. 
Voltunk egy lagzin, és egy kicsit beittam. De semmi ilyen, hogy a földön fetrengtem, ilyet soha nem csinálok. Ilyet egy nő, meg alapból, senki ne csináljon. És hát így táncoltam meg minden. És azért az látszik valakin, főleg józan fejjel. Ö soha nem iszik, vagy csak ennyi bort, és már attól is úgy van, hogy úristen, mennyire berúgtam. És akkor is, nem szóltak hozzám egy hónapig, na jó, nem egy hónapig, de egy hétig, hogy én ott mennyire berúgtam, és hogy mit gondoltak rólam, meg mit tudom én.

Zsófi „eltévelyedésénél” és az arra érkező retorziónál nem az az érdekes, hogy a család hogyan reagál, bár a szeretetmegvonás mindig nagyon erős és pusztító büntetés lehet még egy felnőtt esetében is, hanem az, ahogy Zsófi értékeli ezt. Bár azt érzi, hogy semmi rosszat nem tett, de gyorsan hozzáteszi, hogy azért egy nő ilyet meg olyat ne csináljon. Talán még nem jutott el oda, hogy az ôt ért ítéletet és kritikát ő maga ne alkalmazza másokra, mivel itt egy a társadalmi változással kapcsolatos feszültségről és erre a diszkrepanciára adott családi válaszról van szó, ami tovább él benne is.

Megmaradt egy kicsit, hogy feszélyez az, hogy rövidnadrágban elmenjek valahova, én azt gondolom, hogy lehet, hogy ez konzervatív, jó, most egy ilyen hosszúságú nadrág az oké, de mit tudom én, egy csomó csaj, elnézést a kifejezésért, ilyen picsanadrágok, annyira közönségesek. Egy nőnek nem kell mindent megmutatni.

Itt is például, hogy egy nőnek nem kell mindent megmutatni. Ez nem azt jelenti, hogy ne lehetne egy embernek személyes véleménye a közösségi normákról, de jó, ha látjuk, hogy ez a vélemény nem csak egyéni intenciók következménye, hanem ugyanazt a mintát viszi tovább, amit ő még otthon annyira nehezményezett. Amikor az ő hátán csattant a falusi normákból szőtt ostor, az jobban fájt, mint amikor ő sújt le valaki másra ugyanezért. Zsófinak valójában a generációkon átívelő patriarchális berögződésekkel kellett megküzdenie:

(...) Amikor anyám beiratkozott a semmiből, egyedül, megteremtette magának azt, hogy el tudjon menni föiskolára, nagyon rossz körülmények között élt, de hogy tanult. (...) És amikor elment föiskolára, egyébként (szakma), akkor is így mondta neki, hogy neked ez úgyse fog sikerülni, mikor így hazament, akkor anyának tanulnia kellett volna, és magyarázott neki folyamatosan.

Anya szerintem, ahogyan nevel, azt ő magának csinálta, magának teremtette meg. Valahol biztos a mamájának a hatása is benne van, egy kicsit. De hogy ő sok mindent... Apám meg azt hozza, amit otthon látott. Tehát az ő apja is úgy nevelte, ilyen vaskalaposan. Náluk nem volt ez a „pötyi” gyere ide meg minden. (...) őket is ilyen nagyon keményen nevelték, és ott is a mamám volt, aki ezt a szeretet részt megadta, a tatám meg ilyen elérhetetlen ember volt mindig.

Zsófi „lázadása” nem egyedülálló, de mindenképp egyedi. A családi legendárium fontos része az anya, aki a semmiből nemcsak hogy tanulni ment, de a saját gyülölködő anyjának a terhét lerakva képes volt szeretetteljes szülővé válni. Még ha a megélt élettörténet talán azt is mutatja, hogy ez nem mindig sikerült úgy, ahogy Zsófi szerette volna, de mégis, a nagymamával összehasonlítva, akit egy narcisztikus, gyülölködő asszonyként ír le, ez nagy eredmény. A társadalmi korlátokra és kényszerítő erőkre nemet mondva az individuum, a nő, ledobja láncait és elindul az úton. Az, hogy ez az út egy autoriter, az érzelmeit kimutatni nem tudó férj „karjaiba” vezet, már egy másik történet. 
Aztán rájöttem, hogy ezek a férfiak engem soha nem fognak elismerni. (...) Ha leteszel elé egy nőt, hogy tessék, itt van, akkor se. Vagy akármilyen eredményt, akkor se! Mert akkor is csak egy nő marad. Aztán rájöttem, hogy basszus, ez nekem jó ez? (...) Meg anya is eltürte, hogy mindig egy kicsit kisebb legyen. (...) Ezt nehéz így kimondani, de ha anya mondott valamit, akkor így, jaj, istenem, akkora hülyeség, amit mondasz, pedig nem volt az, csak ez arról szólt, hogy ő nő. És aztán rájöttem, hogy nekem nem kellett ez.

De mégis, neki nem kell minden mintát továbbvinnie, hiszen a lázadás modellje megvan, az anya az életének egy pontján tudta azt mondani, hogy neki ez nem kell, és annak ellenére, hogy egy másik ponton megállt, Zsófinak nem kell. Átveheti és át is veszi a stafétabotot, és megy tovább. Mert neki ez nem kell. Több kell.

Zsófi arra használja a sportot, hogy a giddensi rutinizáció által megteremtse azt az ontológiai biztonságot, amivel nyugodtan tud mozogni az őt körülvevő örökké változó világban. És nem mellesleg, hogy szembeszálljon az őt gúzsba kötő, mozdíthatatlannak tűnő strukturális kényszerítőerőkkel. A narratívában egyaránt megjelenik a sport és a test patológiás és emancipatorikus eszközként való használata, hiszen Zsófi majdnem belehal a kényszerességébe, majd pedig beáll egy egyensúlyi állapot, ahol a mozgás és a test valóban mankóként szolgálhat az öndefinícióban.

\section{Záró megjegyzések}

Dolgozatomban azt állítom, hogy a késő modernitás mint a kortárs társadalmakat leginkább meghatározó, sajátos jegyekkel rendelkező és kihívásokat hordozó korszak olyan, eddig soha nem látott módon presszionálja az egyént az autonóm döntések meghozatalára, mint még soha a történelem során. És most elöször szinte semmilyen segítséget nem kap a cselekvő. A minden eddiginél nagyobb szabadság a választásra minden eddiginél nagyobb magárahagyottsággal párosul. A döntéseiért magának kell vállalnia a felelősséget, és ha elbukik, akkor azt nem ruházhatja át másra, hanem csak saját maga lehet a „hibás” életstratégia okozója. Önmaga „,nagy árnyékává, vagy épp „megváltójáva”” válhat, attól függően, hogy emancipatorikusan vagy patologikusan viszonyul a döntési alternatívák végtelenné válásához. Az életutak individualizálódása miatt nincsenek standard életstratégiák, és az individuális reflexív potenciál óhatatlanul túlcsordul az egyénen, és reflexívvé teszi magát a társadalmi struktúrát is, ezáltal egy folyamatos táncra kényszerítve az egyénre ható strukturális erőt a rá visszaható egyéni erővel. Ebben a dialektikus körforgásban nem csak egyszerủen individualizálódik a cselekvő, de egyedivé válik. Amit az individuumszociológusok szingularitásnak hívnak, az nem egyszerüen egy sajátos életstratégia, hanem organikus reakció a megváltozott strukturális szerkezetre, és nincs két ugyanolyan válasz. Ugyanakkor ez a megváltozott öndefiníciós igény és kényszer nem zárja ki vagy teszi semmissé azt a tényt, hogy még mindig emberi lényekről beszélünk, akiknek egyik legmaghatározóbb attribútuma az érzelem.

Elemzési keretemben az ontológiai biztonság megszerzése nem elválasztható az elismerés-megvetés tengelyén helyet foglaló egyén szeretetpercepciójától. A biztonság úgy teremthető meg, ha ezt az elismerést megkapja társadalmi, jogi, érzelmi szinten. Azt állítom, hogy egy ilyen, az elismerésért és az ontológiai biztonságért folytatott harcban használt eszköz lehet a sport. Hogy a futás robbanásszerủ elterjedése a fővárosban nem írható egyszerüen 
a divat vagy a marketing számlájára, hanem az általános egzisztenciális szorongásra adott válaszként is értelmezhető. Meggyőződésem, hogy a szociológiának és a szociológusnak van szerepe az egyéni „elakadások” magyarázatában, ha nem is mentálhigiénés segítőként, de a környezet és az egyén összecsapásakor megszülető egzisztenciális nyomás során fellépő szorongások makro- és mikroszintü társadalmi okainak magyarázatakor. Hogy olyan, a mindennapi életben is relevánsnak számító tudást is kell termelni, amely az emberek számára befogadható, érthető és használható. Amivel kapcsolatban azt érzik, hogy elmond valamit a világukról, és segít is annak megértésében, a saját helyzetükre való rátekintésben, az esetleges megoldások keresésében.

\section{Hivatkozott irodalom}

Balish, SheaMichael, Mark Eys és Albrecht Schulte-Hostedde (2013): Evolutionary Sport and Exercise Psychology. Integrating Proximate and Ultimate Explanations. Psychology of Sport and Excercise 14(3): 413-422. DOI: https://doi.org/10.1016/j.psychsport.2012.12.006 (letöltve: 2016. január 3.).

Beck, Ulrich (2003): A kockázat-társadalom. Út egy másik modernitásba. Századvég - Andorka Rudolf Társadalomtudományi Társaság.

Beck, Ulrich (1997): Túl renden és osztályon? Társadalmi egyenlőtlenségek, társadalmi individualizációs folyamatok és az új társadalmi alakulatok, identitások keletkezése. In A társadalmi rétegződés komponensei. Válogatott tanulmányok. Angelusz Róbert (szerk.). Budapest: Új Mandátum, 418-468.

Berger Viktor (2013): A tér problémája Anthony Giddens társadalomelméletében. Replika (82): 25-53. Interneten: http://replika.hu/replika/82-03.

Bettelheim, Bruno (2014): Az elég jó szülő. Könyv a gyermeknevelésröl. Budapest: Park.

Biczó Gábor (2004): Az idegen - Variációk Simmeltől Derridáig. Debrecen: Csokonai.

Boltanski, Luc (2002): Létezik-e hálózati morál? Igazolás és kritika a kapitalizmus új képződményeiben. In Forrásvidékek. Társadalomtudományi tanulmányok Némedi Dénes 60. születésnapjára. Felkai Gábor, Molnár Attila Károly és Pál Eszter (szerk.). Budapest: Új Mandátum, 412-425.

Braudel, Fernand (2004): A mindennapi élet struktúrái. A lehetséges és a lehetetlen (Anyagi kultúra, gazdaság és kapitalizmus, XV-XVIII. század). Budapest: Gutta.

Demetrovics Zsolt et al. (2012): Psychometric Properties and Concurrent Validity of Two Exercise Addiction Measures. A Population Wide Study. Psychology of Sport and Exercise (13)6: 739-746. DOI: https://doi. org/10.1016/j.psychsport.2012.06.003.

Dubet, Francois (2012): Az egyén dialogikus felfogása felé. Az egyén mint szociológiai problémákat felvető és megoldó gépezet. Replika (79): 67-76. Interneten: http://replika.hu/replika/79-04.

Szépe András (2012): Elemzések és gondolatok az individuumszociológiákról - Interjú Danilo Martuccellivel. Replika (79): 23-44. Interneten: http://replika.hu/replika/79-02.

Elias, Norbert és Eric Dunninng (2008): Quest for Excitement. Sport and Leisure in the Civilizing Process. In The Collected Work of Norbert Elias. Dunning, Eric (szerk.). University College Dublin Press.

Fromm, Erich (1984): A szeretet müvészete. Budapest: Helikon.

Gergen, J. Kenneth és M. Mary Gergen (2001): A narratívumok és az én mint viszonyrendszer. In Narratívák 5. Narratív pszichológia. László János és Thomka Beáta (szerk.). Budapest: Kijárat, 77-121.

Giddens, Anthony (2013): Élet a poszttradicionális társadalmakban. Replika (82): 55-95. Interneten: http://replika. hu/replika/82-04.

Honneth, Alex (1997): Elismerés és megvetés. Pécs: Jelenkor.

Horkheimer, Max és Theodor W. Adorno (1990): A felvilágosodás dialektikája. Budapest: Gondolat - Atlantisz.

Mead, George H. (1973): A pszichikum, az én és a társadalom szociálbehaviorista szempontból. Budapest: Gondolat. Nietzsche, Friedrich (2003): A Vidám tudomány. Szeged: Szukits.

Ricoeur, Paul (2001): A narratív azonosság. In Narratívák 5. Narratív pszichológia. László János és Thomka Beáta (szerk.). Budapest: Kijárat, 17-27.

Rogers, Carl (2003): Valakivé válni. A személyiség születése. Budapest: Edge 2000.

Sik Domonkos (2012): A modernizáció ingája. Egy genetikus kritikai elmélet vázlata. Budapest: ELTE Eötvös Kiadó. 
Sik Domonkos (2013): Giddens társadalomelmélete. Társadalomkutatás (31)1: 55-71. DOI: https://doi.org/10.1556/ tarskut.31.2013.1.5.

Szabó Lajos (1991): A rendi „szocializmusról” In Rendiség és polgárosodás. Tomori Lajos, Tóth András és Kovách Imre (szerk.). Budapest: MTA Politikai Tudományok Intézete.

Takács Erzsébet (2013): A francia családszociológia és a későmodernitás identitás-diskurzusa. Socio.hu 2013/3: 45-57. DOI: https://doi.org/10.18030/socio.hu.2013.3.45 (letöltve: 2016. január 3.).

Vajda Júlia és Kovács Éva (2002): Élettörténet kutatás a szociológiában. In Forrásvidékek: Társadalomtudományi tanulmányok Némedi Dénes 60. születésnapjára. Felkai Gábor, Molnár Attila Károly és Pál Eszter (szerk.). Budapest: Új Mandátum, 352-367.

Winnicott, Donald W. (2004): A kapcsolatban bontakozó lélek. Válogatott tanulmányok. Budapest: Új Mandátum.

\section{Egyéb hivatkozások}

Rangell, Sammy (2015): The Power of Forgiveness. TEDxDanubia. Interneten: https://www.youtube.com/ watch? $\mathrm{v}=\mathrm{iOzJO6HRIuA}$ (letöltve: 2016. január 3.). 